\title{
Pros and Cons of the Proteomics
}

\author{
Ashish Gupta, Ashutosh Kumar
}

The number of proteins produced by the 30,000-40,000 genes of the human genome is estimated to be three or four orders of magnitude higher. Proteomics is a rapidly developing science. In principle, two main areas in the field of proteomics have been developed, each of them having its pros and cons. These fields are profiling and functional proteomics. The aim of the proteomic profiling is to describe and index the whole set of proteins of a biological sample, which could be an organism, an organ, or a cell, or parts there of like individual's tissue or organelles. In our understanding, both types of proteomics (profiling and functional) are valuable tools complementing other biological methodologies. (Biomed J 2014;37:163-164)

\section{Key words: human genome, pros and cons, protein, proteomics}

A t present, proteomics seems to be the most promising tool for global quality assessment of the production process of blood components and blood derivatives. Table 1 lists the various assays being used to follow changes in platelets with processing and storage of platelet storage lesion. The potential of proteomics as a viable tool for the identification of the platelet storage lesion has since increased dramatically with the development of mass spectrometry (MS), and has required the development of quantitative proteomic techniques such as differential gel electrophoresis (DIGE), isotope-coded affinity tagging (ICAT), and isotope tagging for relative and absolute quantitation (iTRAQ). Proteomics offers the power to characterize protein mixtures in such systems, determine relationships between proteins, resolve their function, and identify protein-protein interactions of interest in the platelet storage lesion process. In this regard, 2D gel electrophoresis, DIGE, iTRAQ, and ICAT can be used to identify protein isoforms that may enable platelets to be stored longer, and resolve conditions under which such platelets store better. As many differential effects on proteins themselves come from post-translational modifications (PTMs) such as phosphorylation or glycosylation, monitoring these will contribute to a better understanding of how platelets function under various storage conditions.

The term "proteome" (PROTEins expressed by agenOME) was coined by Wilkins and colleagues in $1996 .{ }^{[1]}$ Initially the word proteomics referred to the techniques used to analyze a large number of proteins at the same time, but at present, this word covers any approach that yields informa- tion on the abundance, properties, interactions, activities, or structures of proteins in a sample. ${ }^{[2]}$ The number of proteins produced by the 30,000-40,000 genes of the human genome is estimated to be three or four orders of magnitude higher. ${ }^{[3]}$ The reasons for this numerical superiority and complexity are: i) differential splicing of mRNA gene transcripts, which allows a single gene to produce multiple protein products; ii) the capability many proteins have of associating with other proteins to form complexes; and iii) PTMs, which are additional changes that proteins initially translated within a cell may undergo. These are covalent modifications that regulate protein functions, determining their activity state, cellular location, and dynamic interactions with other proteins; the most important and best-studied PTMs are phosphorylation and glycosylation, but many others are common (acetylation, methylation, lipid attachment, sulphation of tyrosine, ubiquitination, and disulfide bond formation) among over 300 different known types. ${ }^{[4]}$

Proteomics is a rapidly developing science, and allows a much more precise assessment of the quality of the blood products transfused to patients. In principle, two main areas in the field of proteomics have been developed, each of them having its pros and cons. These fields are "profiling" and "functional" proteomics. ${ }^{[5]}$ The aim of the proteomic profiling is to describe and index the whole set of proteins of a biological sample, which could be an organism, an organ, or a cell, or parts thereof like individual's tissue or organelles. Profiling also includes differential protein expression levels under specific experimental conditions

From the Department of Pathology, King George's Medical University, Lucknow, Uttar Pradesh, India

Received: May 23, 2013; Accepted: Sep. 03, 2013

Correspondence to: Dr. Ashish Gupta, Department of Pathology, King George's Medical University, Lucknow, India. 226003 , Uttar Pradesh, India. Tel: 91-9451063255; Fax: 91-522-4028872; E-mail: ashineuro@ gmail.com

DOI: $10.4103 / 2319-4170.125652$ 
Table 1: Assays for quantification and characterization of platelet storage lesion

\begin{tabular}{|c|c|}
\hline Type of analysis & Method \\
\hline $\begin{array}{l}\text { Routine assays in transfusion } \\
\text { Practice }\end{array}$ & $\begin{array}{l}\text { Visual inspection } \\
\text { Qualitative swirling } \\
\text { Platelet count } \\
\text { Concentrate volume } \\
\mathrm{pH}^{*} \text { and leukocyte content }\end{array}$ \\
\hline $\begin{array}{l}\text { Assays primarily for } \\
\text { research application } \\
\text { Platelet morphology }\end{array}$ & $\begin{array}{l}\text { Morphology score* } \\
\text { Mean platelet volume (MPV) } \\
\text { Extent of shape change (ESC)* } \\
\text { Hypotonic shock response (HSR)* }\end{array}$ \\
\hline GP expression & Expression of CD41 and CD61 \\
\hline Metabolic activity & $\begin{array}{l}\mathrm{pH}, \mathrm{pO} 2, \mathrm{pCO} 2, \mathrm{HCO} 3 \text { changes } \\
\text { Lactate production } \\
\text { Glucose consumption } \\
\text { Intracellular calcium } \\
\text { ATP/ADP ratio* }\end{array}$ \\
\hline Platelet aggregation & $\begin{array}{l}\text { Spontaneous aggregation } \\
\text { Response to dual agonists }\end{array}$ \\
\hline Coagulation & Fibrinogen binding \\
\hline Platelet activation & $\begin{array}{l}\text { CD62 P-selectin expression } \\
\text { Annexin V binding }\end{array}$ \\
\hline Platelet lysis & $\begin{array}{l}\text { Supernatant LDH content } \\
\text { Lysate vWF: Ag levels }\end{array}$ \\
\hline UV and gamma irradiation & $\begin{array}{l}\text { Nucleic acid core } \\
\text { RNA crosslinking }\end{array}$ \\
\hline Proteomics & $\begin{array}{l}\text { Differential gel electrophoresis (DIGE) } \\
\text { Isotope-coded affinity tagging (ICAT) } \\
\text { Isotope tagging for relative absolute } \\
\text { quantitation (iTRAQ) }\end{array}$ \\
\hline In vivo assays & $\begin{array}{l}\text { Corrected count increment }(\mathrm{CCI}) \\
\text { Bleeding time studies } \\
\text { Radiolabeled survival (Cr-51, In-111) } \\
\text { Biotin-labeled survival }\end{array}$ \\
\hline
\end{tabular}

*In vitro tests correlating with platelet viability or the comparison of different types or origins of sample material. Thus, proteomic profiling describes the inventory of proteins at a particular point of time. In contrast to the more static approach of proteomic profiling, the term "functional proteomics" encompasses direct functional aspect, like enzyme activity, protein interactions, and PTMs. Although these two experimental approaches cannot be seen completely separate, profiling has been regarded to be of minor biological relevance due to its descriptive nature. However, such an opinion does not seem justified, since the cataloging of existing proteins is a basis to generate new hypotheses which trigger further biological investigations; on the other hand, functional proteomics is based on protein profiling, since one needs to know which protein to search for when it is intended to focus on a subset of proteins that are functionally coupled. In our understanding, both types of proteomics ("profiling" and "functional") are valuable tools complementing other biological methodologies.

\section{REFERENCES}

1. Wilkins MR, Sanchez JC, Gooley AA. Progress with proteome projects: Why all proteins expressed by a genome should be identified and how to do it. Biotechnol Genet Eng Rev 1996;13:19-50.

2. Page MJ, Griffiths TA, Bleackley MR. Proteomics: Applications relevant to transfusion medicine. Transfus Med Rev 2006;20:63-74.

3. Marko-Varga G, Fehniger TE. Proteomics and disease: The challenges for technology and discovery. J Proteome Res 2004;3:167-78.

4. Thiele T, Steil L, Völker U, Greinacher A. Proteomics of blood-based therapeutics. Bio Drugs 2007;21:179-93.

5. Choudhary J, Grant SG. Proteomics in postgenomic neuroscience: The end of the beginning. Nat Neurosci 2004;7:440-5. 